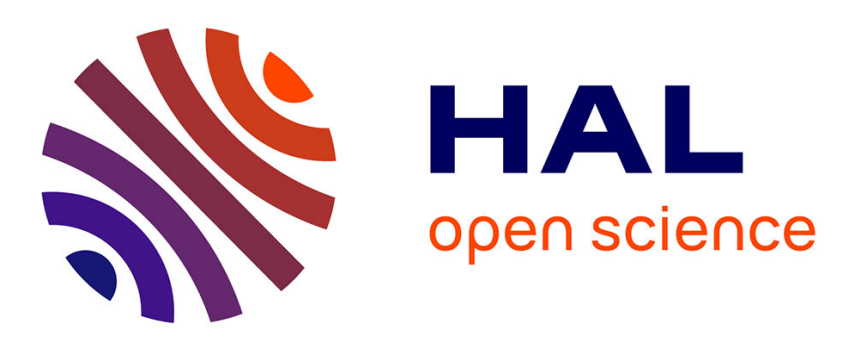

\title{
Chemical and physicochemical characterizations of the water-soluble fraction of the Commiphora Africana exudate
}

\author{
Abdellatif Dahi, Bah Mohamed-Lemine Abdellahi, Mohamed Fadel Deida, \\ Nicolas Hucher, Catherine Malhiac, Frédéric F. Renou
}

\section{To cite this version:}

Abdellatif Dahi, Bah Mohamed-Lemine Abdellahi, Mohamed Fadel Deida, Nicolas Hucher, Catherine Malhiac, et al.. Chemical and physicochemical characterizations of the watersoluble fraction of the Commiphora Africana exudate. Food Hydrocolloids, 2019, 86, pp.2-10. 10.1016/j.foodhyd.2017.10.032 . hal-02181664

\section{HAL Id: hal-02181664 \\ https://hal-univ-lemans.archives-ouvertes.fr/hal-02181664}

Submitted on 25 Oct 2019

HAL is a multi-disciplinary open access archive for the deposit and dissemination of scientific research documents, whether they are published or not. The documents may come from teaching and research institutions in France or abroad, or from public or private research centers.
L'archive ouverte pluridisciplinaire HAL, est destinée au dépôt et à la diffusion de documents scientifiques de niveau recherche, publiés ou non, émanant des établissements d'enseignement et de recherche français ou étrangers, des laboratoires publics ou privés. 


\section{Chemical and physicochemical characterizations of the water-soluble fraction of the Commiphora Africana exudate}

Abdellatif Dahi ${ }^{\mathrm{a}}$, Bah Mohamed-Lemine Abdellahi ${ }^{\mathrm{a}, \mathrm{b}}$, Mohamed Fadel Deida ${ }^{\mathrm{b}}$, Nicolas Hucher* $^{*}$, Catherine Malhiac ${ }^{\mathrm{a}}$, Frédéric Renou ${ }^{\mathrm{a}}$

\footnotetext{
${ }^{\mathrm{a}}$ Normandie Univ, UNILEHAVRE, FR 3038 CNRS, URCOM, 76600 Le Havre, France.

${ }^{\mathrm{b}}$ University of Nouakchott, Faculty of Sciences and Technics, LCME, Nouakchott, Mauritania.

* Corresponding author. N. Hucher, URCOM, Université le Havre Normandie, 25 rue philippe Lebon - BP 1123 76063 le Havre cedex FRANCE - Tel.: +33 232744399; fax: +33 232744391. E-mail address: nicolas.hucher@univ-lehavre.fr
}

\section{$\underline{\text { Abstract }}$}

The present study focuses on the chemical and physical characterization of the watersoluble fraction of the Commiphora Africana exudate. The chemical analysis proved that this fraction is mainly composed of carbohydrates and hydrophobic amino acids. Size exclusion chromatography (SEC) revealed the presence of three distinct polysaccharide populations that are all bonded to protein. In addition, both SEC and rheology demonstrated that the gum owns highly compact structure that suggests an AGP-like polymer. commiphora Africana gum exhibits excellent surface activity at concentration 2 orders of magnitude lower than the reference, acacia gum and was attributed to the fact that the three populations contribute to the surface tension lowering. This remarkable property has been confirmed by preliminary experiments on model emulsions and suggests a very promising application in formulation.

\section{$\underline{\text { Keywords }}$}

Commiphora Africana exudate; water-soluble fraction; chemical composition;

Arabinogalactan-Protein-like polymer; Surface activity; compact structure

\section{Introduction}

Hydrocolloids own many industrial applications in pharmaceutic, cosmetic or food products. Their applications are based on their functional properties, for example, their ability to form viscous solutions at low concentration, or their ability to stabilize emulsions. The possible surface activity of several food gums has been studied in order to evaluate their 
potential emulsifying properties (Dickinson, 2003; Garti \& Reichman, 1993; Phillips \& Williams, 2004; Phillips \& Williams, 2009).

Among hydrocolloids, naturally produced ones show multiple benefits: they are biodegradable, less toxic and have activity over wide temperature, $\mathrm{pH}$ and ionic strength ranges. This may explain the intensive search of new natural gums and the effort to characterize their functional properties (Grein et al., 2013); (Ozaki, Oki, Suzuki, \& Kitamura, 2010); (Steinhorn, Sims, Carnachan, Carr, \& Schlothauer, 2011); (Vinod et al., 2008).

Commiphora Africana [A. rich] Engl. is a tropical and subtropical plant of the genus Commiphora (Burseracea) and widespread over Africa. Hence, Commiphora Africana are found across the south part of Sahel, from West (Mauritania) to East (Ethiopia). The Commiphora genus is known to produce resinous exudates largely studied because of their historical medicinal use (Shen, Li, Wang, \& Lou, 2012). Hence, there is a rich literature concerning the chemistry of Myrrh, from Commiphora Myrrha, opopanax from Commiphora Molmol or Commiphora Mukul (Hanus, Rezanka, Dembitsky, \& Moussaieff, 2005) which are known to contain large amount of various hydrocolloids. In many case, these exudates are used by traditional medicine, including their oral medications (Lemenih, Abebe, \& Olsson, 2003); (Abdellahi, 2013). Concerning Commiphora Africana although, to our knowledge, only an old study by Jessenne (Jessenne, Bezanger-Beauquesne, Pinkas, \& Trotin, 1974), took interest in the chemical composition of its exudate. Unfortunately, the authors could not certify the origin of their studied gum (Bdellium) because, as stated in the $\mathrm{PhD}$ thesis of Jessenne (Jessenne, 1974), it came from a local traditional market. Recently, Gundidza et al. (Gundidza et al., 2011) conducted a viscosimetric analysis of a gum resin from Commiphora Africana, unfortunately without a previous purification of the hydrocolloids parts.

In this paper we will present the first chemical and physicochemical analyses of the water-soluble part of the Commiphora Africana exudates after intensive purification. The aim of this study is to elucidate the fine structure of this fraction and to determine the relationship between the structure and the functional properties, which, to the best of our knowledge, has never been done so far.

\section{Materials and methods}

\subsection{Materials}

Commiphora Africana $(C A)$ gum was extracted from air-dried exudates of the $C A$ tree in Africa. The studied trees are located in the province of Rosso (Wilaya Trarza) in the south of 
Mauritania, on the right bank of the Senegal River. The exudates (nodules), were collected manually, two weeks after wounding, during the month of April. Nodules were air dried and stored in polyethylene bags. They present a dark reddish brown colour.

Monosaccharides and L-amino-acids, used as standards, were obtained from SigmaAldrich (Saint Quentin Fallavier, France) (purity $\geq 99 \%$ ). All other chemicals used were of analytical grade and ultrapure water $(18.2 \mathrm{~m} \Omega$ resistivity) was used in all experiments.

\subsection{CA gum Extraction and purification}

$C A$ exudates (nodules) were frozen with liquid nitrogen and powdered in a high-speed mechanical blender. $10 \mathrm{~g}$ of the obtained powder was poured in water $\left(1000 \mathrm{~cm}^{3}\right)$ and stirred for $30 \mathrm{~h}$ at $70^{\circ} \mathrm{C}$. The suspension was clarified by centrifugation at $2000 \mathrm{~g}$ for $10 \mathrm{~min}$ to remove insoluble part and the resultant solution was freeze-dried. The resulting powder was again dissolved in water at room temperature and precipitated with absolute ethanol. The clear supernatant was sucked out after centrifugation at $20^{\circ} \mathrm{C}$ for $5 \mathrm{~min}$ at $2000 \mathrm{~g}$, and the insoluble fraction (gum) was dried under vacuum to remove traces of solvents. The dried solid was again dissolved in water, and finally freeze dried. This gave a cotton-like and slightly white $C A$ gum. The overall yield was $38 \% \pm 2 \%$.

\subsection{Preparation of CA gum solutions}

$C A$ gum was dispersed in water at the target concentration (weight \%). Dispersions were gently stirred at $35^{\circ} \mathrm{C}$ for $4 \mathrm{~h}$, and left at $3 \pm 1^{\circ} \mathrm{C}$ overnight for complete hydration. Then, filtration using syringe filter $(0.45 \mu \mathrm{m}$, cellulose acetate membrane) gave clear solutions.

\subsection{Chemical composition analysis}

Moisture and ash content of the $C A$ gum were measured by Thermal Gravimetric Analysis (Setaram Setsys 12) realized between 30 and $900^{\circ} \mathrm{C}$ at a heating rate of $10^{\circ} \mathrm{C} / \mathrm{min}$ under nitrogen.

The total protein content was estimated by the Bradford protein assay taking bovine serum albumin (BSA) as standard.

\subsection{Specific optical rotation}

The specific optical rotation $\left([\alpha]_{589}^{25^{\circ} \mathrm{C}}\right)$ of a $2.5 \mathrm{~g} / \mathrm{L}$ gum solution was measured at $25^{\circ} \mathrm{C}$ with a Perkin Elmer polarimeter (model $214 \mathrm{MC}$ ) at wavelength $589 \mathrm{~nm}$, using a $1 \mathrm{dm}$ length cell and a Na lamp. 


\subsection{Monosaccharides composition}

Hydrolysis of the $C A$ gum was conduct trough acidic condition by dissolving the solid in $200 \mu \mathrm{L} 4 \mathrm{M}$ trifluoroacetic acid into a sealed tube flushed with $\mathrm{N}_{2}$ and heated at $100^{\circ} \mathrm{C}$ for 4 $\mathrm{h}$. The solution was then dried under vacuum, dissolved in methanol and dried again twice before precolumn derivatization.

For the precolumn derivatization adapted from Tapie et al. (Tapie, Malhiac, Hucher, \& Grisel, 2008), a 4-(3-methyl-5-oxo-2-pyrazolin-1-yl) benzoic acid (PMPA) solution was prepared immediately before use by the following procedure: PMPA crystals were dissolved in $0.25 \mathrm{M} \mathrm{NaOH}$ methanol-water $(1: 1)$ up to the point at which the $\mathrm{pH}$ stabilized at $7.8-8$ and then complete with methanol-water (1:1) to obtain a final concentration of PMPA of $0.15 \mathrm{M}$. The monosaccharides, either pure references or from the hydrolysis of the $C A$ gum, were incubated with $1 \mathrm{~mL}$ of PMPA solution $(0.15 \mathrm{M})$ at $70^{\circ} \mathrm{C}$ for $2 \mathrm{~h}$. After incubations samples were acidified by $150 \mu \mathrm{L}$ of an aqueous $2 \mathrm{M} \mathrm{HCl}$ solution and shaked up to precipitated most of the excess of derivatization agent. After few minutes samples were centrifuged for $10 \mathrm{~min}$ at $5000 \mathrm{~g}$. Supernatant was sucked out and filtered through $0.2 \mu \mathrm{m}$ nylon membrane.

Separation were carried out with an Agilent 1200 LC system (Agilent Technologies, Massy, France) consisting of a binary pump, autosampler, and column oven. A Sigma-Aldrich Acsentis Express C18 column $(2.7 \mu \mathrm{m}$ 100x2.1 mm I.D. Sigma-Aldrich, Saint-Quentin Fallavier, France) was used at $25^{\circ} \mathrm{C}$. Mobile phases were $20 \mathrm{mM}$ ammonium formate $(\mathrm{pH}$ 4.75) (A) and methanol (B) with a flow rate of $0.4 \mathrm{~mL} \cdot \mathrm{min}^{-1}$ and a gradient profile as follows: $0 \min 10 \% \mathrm{~B} ; 10 \min 10 \% \mathrm{~B} ; 15 \min 30 \% \mathrm{~B} ; 20 \min 30 \% \mathrm{~B} ; 25 \min 70 \% \mathrm{~B} ; 25.1 \min 10 \%$ B. re-equilibration time was $7 \mathrm{~min}$ and injection volume $5 \mu \mathrm{L}$. An Agilent ESI-MS ion trap 6340 (Agilent Technologies, Massy, France) was used for identification and quantification. Mass spectrometry detection was performed in positive mode with optimal conditions determined by direct infusion.

\subsection{Amino acid composition of the protein part}

The overall amino acid composition of the protein part was determined by GC/MS as described by Sassaki et al. (Sassaki et al., 2008). Freeze dried sample of $C A$ gum (1mg) was hydrolysed with $\mathrm{HCl} 6 \mathrm{M}$ at $100^{\circ} \mathrm{C}$ for $20 \mathrm{~h}$. A $0.6 \mathrm{~N} \mathrm{HCl}$ solution in methanol was added to the liberated amino acids or pure amino acids used as reference and these solutions were heated at $100^{\circ} \mathrm{C}$ during $15 \mathrm{~min}$. After drying under $\mathrm{N}_{2}$ stream, the residue containing amino acids methyl esters were treated with pyridine/ $\mathrm{MeOH} / \mathrm{Ac}_{2} \mathrm{O}(300 \mu \mathrm{L} 1: 1: 4)$, then heated at $100^{\circ} \mathrm{C}$ 
during 1 hour. The solutions were directly analysed by GC/MS. GC/MS analyses were performed on a Shimadzu GCMS-QP2010SE equipped with a split injector (1/50) heated at $250^{\circ} \mathrm{C}$. The carrier gas was set up at $1 \mathrm{~mL} \mathrm{~min}^{-1}$. The amino acid acetate methyl esters were separated on a capillary column ZB-5MS-Phenomenex $(\mathrm{L}=30 \mathrm{~m}$; id $=0.25 \mathrm{~mm}$; film thickness $=0.25 \mu \mathrm{m}$ ). The oven temperature was programmed at $50^{\circ} \mathrm{C}$ (hold $2 \mathrm{~min}$ ) to $90^{\circ} \mathrm{C}$ $\left(20^{\circ} \mathrm{C} \mathrm{min}{ }^{-1}, 1 \mathrm{~min}\right)$, then to $280^{\circ} \mathrm{C}\left(5^{\circ} \mathrm{C} \mathrm{min}^{-1}\right)$ then held for $2 \mathrm{~min}$.

Electron Impact (EI) spectra were obtained at $70 \mathrm{eV}$ at $200^{\circ} \mathrm{C}$. The amino acid acetate methyl esters were identified using NIST database and by comparison with pure reference of amino acid acetate methyl esters (MS spectra and retention time).

\subsection{Size exclusion chromatography}

SEC analysis were performed using a shimadzu HPLC system (Shimadzu, Japan) coupled to four detectors: multi-angle laser light scattering (MALLS) operating at eighteen angles (Dawn Heleos II, Wyatt, CA, USA), differential refractometer (Optilab T-rEX, Wyatt, CA, USA), on-line viscosimeter (VISCOSTAR II, Wyatt, CA, USA) and UV-VIS detector activated at $280 \mathrm{~nm}$ (SPD-20A, Shimadzu, Japan). The system was composed of one Shodex OHPAK SB-G pre-column followed by three columns in series (Shodex OHPAK SB 806 HQ, OHPAK SB 805 HQ and OHPAK SB 804 HQ).

Aqueous solution of $C A$ gum ( $1 \mathrm{mg} \cdot \mathrm{ml}^{-1}$ ) was dissolved overnight in milliQ water, then 50

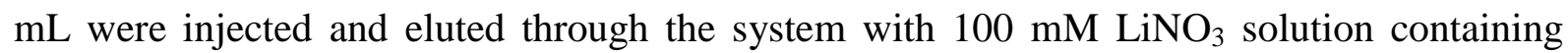
$0.02 \% \mathrm{NaN}_{3}$ at a constant flow rate of $1 \mathrm{~mL} \cdot \mathrm{min}^{-1}$ at room temperature.

\subsection{FT-IR spectroscopy}

IR spectra of the $C A$ gum were measured by a Perkin Elmer Frontier FT-IR spectrometer using the ATR mode ( Diamond/ZnSe crystal). 8 scans were collected for each measurement over the spectral range $4000-650 \mathrm{~cm}^{-1}$ with a resolution of $8 \mathrm{~cm}^{-1}$.

\subsection{Viscosity measurements}

Gum solutions at different concentrations ( 0.01 to $165 \mathrm{~g} / \mathrm{L})$ were prepared in water. Their dynamic viscosity was measured using a rolling Ball Viscometer (Anton PaarAMVn) allowing measurements at different angles $\left(15\right.$ to $\left.85^{\circ}\right)$. The rolling Ball Viscometer uses the simple Höppler principle to measure viscosity. The basic concept is to measure the elapsed time required for the ball to roll under gravity through a sample-filled tube inclined at an angle. First, the tube (1.6 mm diameter) was filled with a gum solution. Then, it was placed in 
the thermostatic measurement chamber and equilibrated to a constant temperature maintained within $\pm 0.1^{\circ} \mathrm{C}$ for about $15 \mathrm{~min}$. Thereafter, rolling times of solution were measured at different temperature $\left(10,20,30,40\right.$ and $\left.50^{\circ} \mathrm{C}\right)$. At each temperature, the angle of tube from the horizontal was varied progressively from $30,40,50,60,70$ to 80 degrees in order to study the flow behaviour of $C A$ gum in solution. At each angle, the measurement was carried out 4 times to determine an average. Viscosities were directly given by the viscometer according to the rolling times.

The intrinsic viscosity $[\eta]$ was determined at $20^{\circ} \mathrm{C}$ using the Huggins equation (1) (Huggins, 1942) by plotting $\eta_{s p} / C$ against the polymer concentration, and subsequently extrapolating to zero polymer concentration (2):

$$
\begin{aligned}
& \frac{\eta_{s p}}{C}=[\eta]+k_{H}[\eta]^{2} C=\frac{\eta-\eta_{s}}{\eta_{s} C} \\
& {[\eta]=\lim _{C \rightarrow 0} \frac{\eta_{s p}}{C}}
\end{aligned}
$$

where $\eta$ and $\eta_{s}$ are the viscosity of the solution and the solvent respectively, $\eta_{s p}$ is the specific viscosity and $C$ and $k_{H}$ are the polymer concentration and the Huggins coefficient, respectively.

\subsection{Surface tension measurements}

Surface tension measurements were made using Du Noüy ring tensiometer (Krüss k11, Germany) with platinum ring at room temperature $\left(25^{\circ} \mathrm{C}\right)$. Gum solutions at concentrations ranging from 0.01 to $35 \mathrm{~g} / \mathrm{L}$ were used.

\subsection{Evaluation of emulsifying properties}

Oil-in-water emulsions were prepared by mixing $0.35 \mathrm{~g}$ of orange essential oil, provided by Laboratoire Rosier Davenne (Montfavet, France) and $4.65 \mathrm{~g}$ of $C A$ gum solutions at 10 and $50 \mathrm{~g} / \mathrm{L}$. For comparison, commercial Acacia Senegal gum (food grade), provided by Alland \& Robert (Port Mort, France) was also tested in the same conditions.

First, gum solutions were prepared and kept at rest for $24 \mathrm{~h}$. The oil phase was then dispersed in the gum solutions under strong shear using a T10 basic ULTRA-TURRAX® (IKA, Germany) at $14450 \mathrm{rpm}$ for $5 \mathrm{~min}$ at $20^{\circ} \mathrm{C}$. All emulsion samples were kept at $20^{\circ} \mathrm{C}$ after preparation and sheltered from the light after emulsification.

Characterization of size and size distribution of emulsions during aging were conducted using static laser diffraction apparatus SALD-7500nano (Shimadzu, japan). 


\section{Results and discussion}

\section{1 $C A$ gum main characteristics}

The main composition of $C A$ gum is summarized in Table 1. Two major groups of exudates can be distinguished, on the one hand the resin which are soluble in organic solvents (e.g. pine resin) and on the other hand the gum which are soluble in water (e.g. acacia gum). This first shows that when compared to other well characterized exudates, in the exudate from Commiphora Africana trees the water-soluble gum is a minor fraction, representing only about $40 \%$ of the total content. This is in accordance with the characteristics of exudates from the other Commiphora species where 30-60\% of this exudates are water-soluble gum, and 25$40 \%$ are ethanol soluble resin(Hanus et al., 2005). So the Commiphora Africa exudates can be considered as a resin-gum exudate. This low water-soluble fraction points out the importance of purification prior to any measurement and thus data obtained without proper purification have to be taken with extreme caution. $C A$ gum showed to be mostly composed of carbohydrates $(80 \%)$ with a low content of inorganic matter but a relatively high content of proteins (Table 1). Hence, when compared to many others gums from trees (acacia gums: 1.42.2\% (Idris, Williams, \& Phillips, 1998), Tragacanth Gums: 2-4 \% (Balaghi, Mohammadifar, \& Zargaraan, 2010) or Barijeh gum: 4.3\% (Mohammadzadeh Milani et al., 2007), the 10.2\% measured as protein content in $C A$ gum could have been related to impurities through unwashed free proteins. But SEC measurement(Figure 1), and especially from the UV-Vis detector, showed that the UV signal, generally the signature of the presence of amino acid, is very similar to the RI signal on the whole range of elution time. Hence, this suggests that the carbohydrates own covalently bonded protein with similar ratio, which will be discussed in more detail later.

\subsection{FT-IR}

The FTIR spectrum of $C A$ gum is given in Figure 2. Two characteristic peaks of polysaccharides were observed at 3286 and $2934 \mathrm{~cm}^{-1}$, which were related to stretching vibration modes of $\mathrm{OH}$ bound to carbons and $\mathrm{C}-\mathrm{H}$ stretching vibration, respectively. The bands at $1637 \mathrm{~cm}^{-1}$ and $1539 \mathrm{~cm}^{-1}$ are attributed to the amide I and amide II bands of the polypeptidic backbone of glycoproteins and proteoglycans (Barth, 2007). However, polysaccharides containing uronic acids will also give bands close to $1637 \mathrm{~cm}^{-1}$ and to 1413 $\mathrm{cm}^{-1}$ that were attributed to the vibration of $\mathrm{C}=\mathrm{O}$ and the deprotonated carboxylic function respectively (Boulet, Williams, \& Doco, 2007). The region between 1200 and $600 \mathrm{~cm}^{-1}$ 
represents the so-called carbohydrate fingerprints. This region is typical of the skeletal stretching vibrations of the backbone and side chains of polysaccharides, which is dominated by ring vibrations overlapped with stretching vibrations of $(\mathrm{C}-\mathrm{OH})$ side groups and $(\mathrm{C}-\mathrm{O}-\mathrm{C})$ glycosidic bond vibrations (Kačuráková, Capek, Sasinková, Wellner, \& Ebringerová, 2000). All these observations are in accordance with the presence of both polysaccharides and proteins in $C A$ gum. (Lopez-Torrez, Nigen, Williams, Doco, \& Sanchez, 2015)

\subsection{Monosaccharides composition by HPLC}

The composition of the monosaccharides obtained by hydrolysis of $C A$ gum is given in Table 2. The analytic procedure allowed quantifying the derivated monosaccharides and, if any, the di or three-saccharides not fully hydrolysed. The two major monosaccharides found were arabinose and galactose (47\% and $28 \%$, respectively). Also these two monosaccharides are usually present in exudates of Commiphora species (Hanus et. al. 2005). Then galacturonic acid represent about $7 \%$ of the total monosaccharide. Finally, mannose, xylose, glucosamine and fucose are also present at relatively high percentage (between 4 and 5\%) which is quite unusual for plant gums, especially for glucosamine. Indeed, for instance, Wiendl et. al. (Wiendl, Müller, \& Franz, 1995) reported small amount of mannose (less than $3 \%$ ) in Myrrh from unprecise botanic origin among with larger amount of 4-OMethylglucuronic acid (up to 43.9\%). Fucose was also identified by TLC in gum resin of Commiphora Mukul (Bose \& Gupta, 1964). If Jessenne et. al. (Jessenne et al., 1974) reported galacturonic acid from gum of Bdellium, there were no evidence that this gum samples came from identified botanic origin, even if stated "probably from Commiphora Africana". This is the only paper, to-date, that discussed the chemical composition of exudate from Commiphora Africana. Glucosamine is far less common in plant exudates, but already reported in botanic species from Acacia, Araucaria and some others (Anderson, Hendrie, \& Munro, 1972) and is closely related to the linkage of proteins to carbohydrate in glycoproteins and proteoglycans.

\subsection{Amino acids composition}

To our knowledge, the amino acid composition of the proteins from Commiphora Africana gum had never been determined. The main amino acids of Commiphora Africana are given in Table 3. The major amino acids therefore are Hydroxyproline (Hyp 22.7\%), Proline (18.1\%), Alanine (14.9\%), PhenylAlanine (8.7\%), Leucine (7.1\%), Serine (6.2\%), Glutamic and aspartic acids $(6.1 \%$ and 5.3\%). Hyp is also described to be the main amino acid in Myrrh (Commiphora molmol) exudate. (Wiendl, Müller \& Franz 1995). Hyp is also the main amino 
acid in case of Arabinogalactan-Protein (AGP) structure such as AGP fraction of acacia gum. Furthermore, this amino acid is often described as the link between the protein fraction and the polysaccharide fraction (Mahendran, Williams, Phillips, Al-Assaf, \& Baldwin, 2008).

One can notice a high percentage of phenylalanine which can explain the strong absorbance at 280nm (Figure 1). Furthermore, the major identified amino acids were hydrophobic, which is usually related to compact globular proteins.

\subsection{Viscosity measurements}

The viscosity of many liquids depends exponentially on temperature, and the most appropriate model that best explains the temperature dependence of the viscosity of macromolecules is the Arrhenius equation which is expressed as:

$\eta=\eta_{r e f} \exp \left(\frac{E_{a}}{R T}\right)$

where $\eta$ (Pa.s) is viscosity, $R$ is the gas constant $\left(8.31 \mathrm{~J} . \mathrm{K}^{-1} \cdot \mathrm{mol}^{-1}\right), T(\mathrm{~K})$ is temperature, $E_{a}(\mathrm{~J} / \mathrm{mol})$ is the Arrhenius activation energy and $\eta_{\text {ref }}(\mathrm{Pa} . \mathrm{s})$ is the viscosity of the solution at the reference temperature $\left(\operatorname{Tref}=20^{\circ} \mathrm{C}\right.$, in this study).

The values of activation energy evolved slightly from 17 to $23 \mathrm{KJ} . \mathrm{mol}^{-1}$ for $C A$ gum solutions with concentrations from 20 to $165 \mathrm{~g} / \mathrm{L}$. It is well known that the activation energy reflects the flexibility and interactions of macromolecules. For instance, acacia and cashew gums branched polysaccharide with few interactions, have comparable Ea values of respectively $15 \mathrm{~kJ} \cdot \mathrm{mol}^{-1}$ (Varfolomeeva, Grinberg, \& Tolstogusov, 1980) and $15.6 \mathrm{~kJ} . \mathrm{mol}^{-1}$ (de Paula \& Rodrigues, 1995) for a $20 \mathrm{~g} / \mathrm{L}$ solution. On the contrary, linear polymers strongly bonded by intra and intermolecular interactions involving hydrogen bonding show high activation energies. For example, xanthan gum exhibits Ea value about $70-80 \mathrm{~kJ}^{\mathrm{mol}}{ }^{-1}$ for concentration ranging from 1 to $10 \mathrm{~g} / \mathrm{L}$ (Renou, Petibon, Malhiac, \& Grisel, 2013). It appears clearly that the viscosity behaviour of $C A$ gum is closer to branched polysaccharides, than to linear ones. Accordingly, the intermolecular interactions between polysaccharide chains in $C A$ gum are weak.

On the other hand, $C A$ gum solutions from 20 to $110 \mathrm{~g} / \mathrm{L}$ exhibits at $20^{\circ} \mathrm{C}$ viscosities ranging from 1.06 to $10.3 \mathrm{mPa}$.s. These very low (for this range of concentration) values are similar to that of acacia gum in solutions up to $100 \mathrm{~g} / \mathrm{L}$ (Glicksman, 1969). The low and newtonian (as will be seen below) viscosity at higher concentrations is a second sign of weak intermolecular interactions between polymer chains. All these results indicate probably a polymer structure in $C A$ gum of high compactness. 


\subsubsection{Intrinsic viscosity}

The intrinsic viscosity is a measure of the hydrodynamic volume occupied by a macromolecule, which is closely related to both the conformation and size (weight) of the macromolecular chain in a specific solvent (Lai \& Chiang, 2002). Intrinsic viscosity of $C A$ gum was determined according to the Huggins equation (3), as explained before. To this end, dilute solutions was used, ranging from 20 to $80 \mathrm{~g} / \mathrm{L}$. The obtained $[\eta]$ value for $C A$ gum was $20.3 \mathrm{ml} . \mathrm{g}^{-1}$. Again, this low value was close to that found for acacia gum (Al-Assaf, Phillips, \& Williams, 2005) (Lopez-Torrez et al., 2015).

\subsubsection{Flow behaviour of $C A$ gum}

From viscosity measurements, it was observed that the flow times for all solutions (20 to $165 \mathrm{~g} / \mathrm{L}$ ) decrease proportionally with the tube angle from 30 to $80^{\circ}$, proving that solutions remain Newtonian even at concentrations as high as $165 \mathrm{~g} / \mathrm{L}$.

The power law equation below (4) relating specific viscosity and concentration can be used as an indicator for estimating the conformation of polymer chains (Lai, Tung, \& Lin, 2000):

$$
\eta_{s p}=a C^{b}
$$

where $a$ and $b$ are constants. Figure 3 shows this power-law plot for $C A$ gum solutions at different temperature.. From this plot, it can be seen that both the slope ( $b$ value) and intercept ( $a$ value) remain stable, irrespective to the temperature. This means that the polymer chains adopt the same conformation over the studied temperature range. It has been established that $b$ value greater than one is associated with a spherical or compact conformation, while a value of $b$ less than one is associated with rod like conformation (Lai \& Chiang, 2002). From plots, the $b$ value was around $1.75 \pm 0.05$ (an average of all the slopes). Therefore, the molecular conformation of $C A$ gum is more spherical like than rod like. Again, this result is in good accordance with polymer structure in $C A$ gum of high compactness.

On the other hand, shape factor value was determined to be 2.54 , from equation 5 :

$$
v=\frac{[\eta]}{V_{E}}
$$

where $V_{E}$, the voluminosity, was determined following Antoniou et al. methodology (Antoniou, Themistou, Sarkar, Tsianou, \& Alexandridis, 2010)

A shape factor value of 2.5 suggests that the polymer coils are spherical in nature (Joseph, Devi, \& Rakshit, 1991). This indicates that the effective molecular shape of $C A$ gum 
is spherical. To verify this, the Krieger \& Dougherty model (Krieger \& Dougherty, 1959) was also applied to the data. This model was developed to characterize the volume fraction dependence of the relative viscosity of hard spheres and is frequently used for food systems, using equation (6):

$$
\eta_{\text {rel }}=\left(1-\frac{\phi}{\phi_{\max }}\right)^{-[\eta]_{0} \phi_{\max }}
$$

with $\phi$ and $\phi_{\max }$ the volume fraction and maximum packing volume fraction, respectively, of suspended particles, and $[\eta]_{0}$ the intrinsic viscosity which theoretically depends on particle shape. The $\phi / \phi_{\max }$ term in the equation can then be simply substituted by $C / C_{\max }$, where $C$ is the polymer concentration. According to hard sphere theory, the $\phi_{\max }$ and $[\eta]_{0}$ parameters of Krieger \& Dougherty equation for mono-dispersed spherical systems are 0.64 and 2.5, respectively. Thus, this equation was applied to the experimental data of $C A$ gum (Figure 4). For reasons of clarity and ease of understanding, our results were compared to a linear and spherical star-like polymer (32 arms, considered as relatively dense system) (Vlassopoulos, 2004). A deviation from the Krieger \& Dougherty model (hard spheres) was found for the $C A$ gum. This result indicates that $C A$ gum doesn't exhibit a hard-sphere behaviour. $C A$ gum is also not linear because its behaviour diverges for linear one and is in between linear and the star-like polymer conformation. To conclude, the polymer chains in the $C A$ gum adopts a relatively compact structure. This explains both the low viscosifying properties of $C A$ gum, and the weak intermolecular interactions between chains as evidenced previously by the low $E a$ values. To get deeper into the polymer structure of $C A$ gum, size-exclusion chromatography was used and results are discussed in the next section.

\subsection{Polymer conformation in solution}

Size exclusion chromatography measurements have been carried out with using UV, RI, LS and viscosimetric detectors and the chromatograms are displayed in Figure 1. One can clearly see that the system is composed of three main populations which are quite well defined at 21, 24.5 and 27.4 min elution times, which correspond to 8000000,950000 and $150000 \mathrm{~g} / \mathrm{mol}$, respectively as determined by the LS detector. The main population in number is eluted at $27.4 \mathrm{~min}$, thus corresponding to the latter molecular weight. All the average parameters (on the whole elution time range) are summarized in Table 4. $\mathrm{Mw}$ is about 1300000 g.mol ${ }^{-1}$ while $\mathrm{Mn}$ is $260000 \mathrm{~g} \cdot \mathrm{mol}^{-1}$, proving that the system is highly polydisperse as it is often observed for natural polysaccharide from plants (Eagles, Stephen, \& Churms, 
1993); (Phillips, 2009). In addition, thanks to viscosimetric detector, the intrinsic viscosity was determined and is very close to the one measured by the rolling ball viscometer. The hydrodynamic radius is $14.1 \mathrm{~nm}$, which is quite small for molecule of such a high molecular weight, showed again that the molecules are highly compact. This observation is consistent with the viscosimetric analysis that shows that $C A$ gum behaves as a highly branched polymer.

The UV signal measured at $280 \mathrm{~nm}$ showed a maximum absorbance that correlate with the three main populations at 21,24.5 and 27.4 min elution times. This suggests that the three population own covalently bonded protein with similar ratio, proving that bonded proteins are homogeneously distributed between the three populations. This is an unusual property, very different to what is observed for gums containing glycoproteins such as acacia gum for instance (Phillips, 2009) but that were already found for closely related Myrrh gum (Commiphora molmol) (Wiendl et al., 1995).

\subsection{Surface tension}

The surface activity of $C A$ gum was characterized by measuring the tension at air/water interface according to the Du Noüy's ring method at $25^{\circ} \mathrm{C}$. Figure 5 shows the variation of the surface tension of water as a function of $C A$ gum concentration. Surface tension of ultrapure water at $25{ }^{\circ} \mathrm{C}$ was $71.90 \mathrm{mNm}^{-1}$. One can observe a rapid lowering of the surface tension from 71.90 to $50.43 \mathrm{mN} \cdot \mathrm{m}^{-1}$ for concentration ranging from 0 to $7 \mathrm{~g} / \mathrm{L}$. For higher $C A$ gum concentrations, surface tension remained constant. Critical aggregation concentration (CAC), determine as the concentration at which the surface tension starts to decrease, was determine at $0.2 \mathrm{~g} / \mathrm{L}$ of $C A$ gum. Hence, $C A$ gum reduced the surface tension more efficiently than classic commercial pectin $\left(63 \mathrm{mN} . \mathrm{m}^{-1}\right.$ in apple pectin) (Lutz, Aserin, Wicker, \& Garti, 2009) or Acacia tortuosa (53 mN.m ${ }^{-1}$ ) (Muñoz et al., 2007). In addition, this very low CAC is about 135 times lower than the reference gum (Acacia Senegal), for which CAC is close to $27 \mathrm{~g} / \mathrm{L}$ in the same conditions of measurement (Grein et al., 2013). This may open a promising application of $C A$ gums as efficient surface agent.

\subsection{Emulsifying properties}

Preliminary experiments on simple emulsions (orange essential oil/water) were conducted on $C A$ gum and Acacia Senegal gum for comparison. Figure 6 shows the volume droplet size distribution for o/w emulsions containing 10 and $50 \mathrm{~g} / \mathrm{L}$ of gum (CA and Acacia Senegal), and their monitoring over time at $20^{\circ} \mathrm{C}$. 
At $50 \mathrm{~g} / \mathrm{L}$, the droplet size distribution of the freshly prepared emulsions is very close for both gums. The main population can be seen with a volume mean diameter (D4,3) of $12 \mu \mathrm{m}$. However, for the $C A$ gum, a small population with a D4,3 of $4 \mu \mathrm{m}$ slowly disappeared after few days, probably through Ostwald ripening. In general, and for both gums, no changes in the droplet size distribution nor in the D4,3 were observed during the experiment (up to 10 days).

At $10 \mathrm{~g} / \mathrm{L}$, the droplet size distribution of the freshly prepared emulsions is also very close for both gums. The main population can be seen with a D4,3 of $19 \mu \mathrm{m}$. In case of $C A$ gum, both the droplet size distribution and the mean droplet size remain stable over time, evidencing a powerful emulsifying capacity of $C A$ gum at $10 \mathrm{~g} / \mathrm{L}$. Indeed, this moderate concentration is already at 50 times the CAC of CA gum. In the case of Acacia Senegal gum, a demixing was observed within one hour after the emulsion preparation (as seen in the picture caption figure 6) and thus no monitoring was possible afterwards. At $10 \mathrm{~g} / \mathrm{L}$, Acacia Senegal gum could not create a stable emulsion probably because the used concentration (10 $\mathrm{g} / \mathrm{L}$ ) is below the CAC of this gum (close to $27 \mathrm{~g} / \mathrm{L}$ according to (Grein et al., 2013)). These preliminary results demonstrate the excellent emulsifying properties of CA gum, which is efficient at much lower concentrations than acacia.

\section{Discussion}

All of the chemical analyses of $C A$ Gum lead to a proposed structure for this hydrocolloid that is clearly related to arabinogalactan-like glycoprotein (AGP) structures. First, we showed that the two major monosaccharides were arabinose and galactose, and that, minor ones, galacturonic acid and glucosamine, are usually related to glycoproteins and proteoglycans (Nguema-Ona et al., 2014). Secondly, The $C A$ gum protein fraction is rich in Hyp and its overall composition is also compatible with the AGP nature of the polysaccharides, as stated for acacia gum (Idris et al., 1998).

Besides, the amino acids are mainly hydrophobic, with a large amount of proline, which is consistent with a globular structure of the resulting proteins (Lesser \& Rose, 1990); (Schulz, 1977). This will most likely lead to a compact AGP-like structure, which is consistent with the high compactness that we determined for $C A$ gum.

The present study shows that $C A$ gum lowers the surface tension of water down to $50.43 \mathrm{mN} / \mathrm{m}$ with less than $10 \mathrm{~g} / \mathrm{L}$ of $C A$ gum. Therefore $C A$ gum possesses excellent capacities to lower the surface tension using concentrations at least 100 times lower than acacia gum for the same performance, which would open up promising opportunities in 
formulation. In general, the capacity of food biopolymers to lower the surface tension is related to their chemical structure, concentration, and molecular conformation at the interface (Dickinson, 2011); (López-Franco et al., 2012). More precisely, both the accessibility of the protein moieties to the interface and the net surface charge of adsorbing molecules control the interfacial activity of polymers (Vasile, Martinez, Pizones Ruiz-Henestrosa, Judis, \& Mazzobre, 2016). Some reports have shown that a relatively high protein content is required to provide good interfacial properties. Hence, the interfacial properties of acacia gum were, for example, attributed to the arabino-galactan protein fraction and its high molecular weight in the gum sample (Dickinson, 2011); (Phillips, 2009). In addition, contrary to acacia gum, for which protein are mainly located in one fraction (AGP), for $C A$ gum, the 3 fractions possess covalently bonded protein. Thus, all fractions contribute to the surface tension lowering which may explain the much better surface activity of $C A$ gum.

The preliminary experiments on the emulsifying properties of $C A$ gum showed that 1) $C A$ gum presents excellent stabilizing properties as good as Acacia Senegal gum then 2) CA gum is even more efficient than Acacia Senegal gum at low concentration, thanks to it much lower CAC. These preliminary results prove the effective ability of CA gum to stabilize interfaces and thus it potential interest in formulation.

\section{Conclusion}

The chemical composition of the water-soluble fraction of the Commiphora Africana exudate has been determined for the first time without ambiguity. This gum exudate is manly composed of glycoproteins, which is composed of $79.5 \%$ carbohydrates and $10.2 \%$ proteins. The major monosaccharides found were arabinose $(47 \%)$ and galactose $(28 \%)$ together with galacturonic acid (7\%) and minors one. The major amino acids found were hydroxyproline $(22.7 \%)$, proline $(18.1 \%)$ and alanine $(14.9 \%)$. Rheological measurement among with size exclusion chromatography lead to a proposed structure of an highly compact AGP-like polymer. Whereas the Commiphora Africana gum is composed of three main populations (ranging from 8000000 to 150000 g.mol ${ }^{-1}$ ), they all possess covalently bounded protein. Hence, in accordance with what is expected for AGP-like polysaccharides, the gum showed a great capacity to lower the surface tension in water (down to $50.43 \mathrm{mN} \cdot \mathrm{m}^{-1}$ for a $7 \mathrm{~g} / \mathrm{L}$ solution). In addition, preliminary experiments on simple emulsions gave encouraging results. In further works we will conduct a complete characterization of stabilization capacities of the Commiphora Africana gum, in order to confirm its promising efficiency as surface agent. 


\section{ACKNOWLEDGMENT}

This project was supported by the Ministère des affaires étrangères Française (French Foreign Policy). Bah M-L Abdellahi was recipient of a Doctoral fellowship from the Coopération Française.

\section{References}

Abdellahi, B. M.-L. (2013). Caractérisation chimique et physicochimique de la résine du commiphora africana d'origine mauritanienne en vue de sa valorisation. $\mathrm{PhD}$ Thesis, Université Le Havre Normandie.

Al-Assaf, S., Phillips, G., \& Williams, P. (2005). Studies on acacia exudate gums. Part I: the molecular weight of Acacia Senegal gum exudate. Food Hydrocolloids, 19(4), 647-660. https://doi.org/10.1016/j.foodhyd.2004.09.002

Anderson, D. M. W., Hendrie, A., \& Munro, A. C. (1972). The amino acid and amino sugar composition of some plant gums. Phytochemistry, 11(2), 733-736.

Antoniou, E., Themistou, E., Sarkar, B., Tsianou, M., \& Alexandridis, P. (2010). Structure and dynamics of dextran in binary mixtures of a good and a bad solvent. Colloid and Polymer Science, 288(12-13), 1301-1312. https://doi.org/10.1007/s00396-010-2259-x

Balaghi, S., Mohammadifar, M. A., \& Zargaraan, A. (2010). Physicochemical and Rheological Characterization of Gum Tragacanth Exudates from Six Species of Iranian Astragalus. Food Biophysics, 5(1), 59-71. https://doi.org/10.1007/s11483-009-9144-5

Barth, A. (2007). Infrared spectroscopy of proteins. Biochimica et Biophysica Acta (BBA) Bioenergetics, 1767(9), 1073-1101. https://doi.org/10.1016/j.bbabio.2007.06.004

Bose, S., \& Gupta, K. C. (1964). Structure of C. mukul -Part II. Structure of the Degraded Gum. Indian Journal of Chemistry, 2, 156-158. 
Boulet, J. C., Williams, P., \& Doco, T. (2007). A Fourier transform infrared spectroscopy study of wine polysaccharides. Carbohydrate Polymers, 69(1), 79-85. https://doi.org/10.1016/j.carbpol.2006.09.003

de Paula, R. C. M., \& Rodrigues, J. F. (1995). Composition and rheological properties of cashew tree gum, the exudate polysaccharide from Anacardium occidentale L. Carbohydrate Polymers, 26(3), 177-181. https://doi.org/10.1016/0144-8617(95)00006-S

Dickinson, E. (2003). Hydrocolloids at interfaces and the influence on the properties of dispersed systems. Food Hydrocolloids, 17(1), 25-39.

Dickinson, E. (2011). Mixed biopolymers at interfaces: Competitive adsorption and multilayer structures. Food Hydrocolloids, 25(8), 1966-1983. https://doi.org/10.1016/j.foodhyd.2010.12.001

Eagles, P. F., Stephen, A. M., \& Churms, S. C. (1993). Molecular structures of gum exudates from Hakea species. Phytochemistry, 34(3), 709-713.

Garti, N., \& Reichman, D. (1993). Hydrocolloids as food emulsifiers and stabilizers. Food Structure, 12(4), 3.

Glicksman, M. (1969). Gum Technology in the Food Industry (Vol. 23). Academic Press, New York and London, 1969.

Grein, A., da Silva, B. C., Wendel, C. F., Tischer, C. A., Sierakowski, M. R., Moura, A. B. D., Riegel-Vidotti, I. C. (2013). Structural characterization and emulsifying properties of polysaccharides of Acacia mearnsii de Wild gum. Carbohydrate Polymers, 92(1), 312320. https://doi.org/10.1016/j.carbpol.2012.09.041

Gundidza, M., Mmbengwa, V., Sibambo, S. R., Magwa, M. L., Mushisha, O., Benhura, M. A., Samie, A. (2011). Rheological, moisture and ash content analyses of a gum resin from Commiphora Africana. African Journal of Food Science, 5(4), 188-193. 
Hanus, L. O., Rezanka, T., Dembitsky, V. M., \& Moussaieff, A. (2005). Myrrh - commiphora chemistry. Biomedical Papers, 149(1), 3-28. https://doi.org/10.5507/bp.2005.001

Huggins, M. L. (1942). The Viscosity of Dilute Solutions of Long-Chain Molecules. IV. Dependence on Concentration. Journal of the American Chemical Society, 64(11), 27162718. https://doi.org/10.1021/ja01263a056

Idris, O. H. M., Williams, P. A., \& Phillips, G. O. (1998). Characterisation of gum from Acacia senegal trees of different age and location using multidetection gel permeation chromatography. Food Hydrocolloids, 12(4), 379-388. https://doi.org/10.1016/S0268005X(98)00058-7

Jessenne, M. G. (1974). Les Gommes de deux gommes-résines (Bdellium, Galbanum). PhD Thesis, Université de Lille.

Jessenne, M. G., Bezanger-Beauquesne, L., Pinkas, M., \& Trotin, F. (1974). Gums of two gum resins, bdellium and galbanum. Plant Med Phytother, 8, 241-249.

Joseph, R., Devi, S., \& Rakshit, A. K. (1991). Viscosity behaviour of acrylonitrile-acrylate copolymer solutions in dimethyl formamide. Polymer International, 26(2), 89-92.

Kačuráková, M., Capek, P., Sasinková, V., Wellner, N., \& Ebringerová, A. (2000). FT-IR study of plant cell wall model compounds: pectic polysaccharides and hemicelluloses. Carbohydrate Polymers, 43(2), 195-203. https://doi.org/10.1016/S0144-8617(00)00151-X

Krieger, I. M., \& Dougherty, T. J. (1959). A Mechanism for Non-Newtonian Flow in Suspensions of Rigid Spheres. Transactions of the Society of Rheology, 3, 137-152. https://doi.org/10.1122/1.548848

Lai, L. S., Tung, J., \& Lin, P. S. (2000). Solution properties of hsian-tsao (Mesona procumbens Hemsl) leaf gum. Food Hydrocolloids, 14(4), 287-294.

Lai, L.-S., \& Chiang, H.-F. (2002). Rheology of decolorized hsian-tsao leaf gum in the dilute domain. Food Hydrocolloids, 16(5), 427-440. 
Lemenih, M., Abebe, T., \& Olsson, M. (2003). Gum and resin resources from some Acacia, Boswellia and Commiphora species and their economic contributions in Liban, south-east Ethiopia. Journal of Arid Environments, 55(3), 465-482. https://doi.org/10.1016/S01401963(03)00053-3

Lesser, G. J., \& Rose, G. D. (1990). Hydrophobicity of amino acid subgroups in proteins. Proteins: Structure, Function, and Bioinformatics, 8(1), 6-13.

López-Franco, Y. L., Córdova-Moreno, R. E., Goycoolea, F. M., Valdez, M. A., JuárezOnofre, J., \& Lizardi-Mendoza, J. (2012). Classification and physicochemical characterization of mesquite gum (Prosopis spp.). Food Hydrocolloids, 26(1), 159-166. https://doi.org/10.1016/j.foodhyd.2011.05.006

Lopez-Torrez, L., Nigen, M., Williams, P., Doco, T., \& Sanchez, C. (2015). Acacia senegal vs. Acacia seyal gums - Part 1: Composition and structure of hyperbranched plant exudates. Food Hydrocolloids, 51, 41-53. https://doi.org/10.1016/j.foodhyd.2015.04.019

Lutz, R., Aserin, A., Wicker, L., \& Garti, N. (2009). Structure and physical properties of pectins with block-wise distribution of carboxylic acid groups. Food Hydrocolloids, 23(3), 786-794. https://doi.org/10.1016/j.foodhyd.2008.04.009

Mahendran, T., Williams, P. A., Phillips, G. O., Al-Assaf, S., \& Baldwin, T. C. (2008). New Insights into the Structural Characteristics of the Arabinogalactan-Protein (AGP) Fraction of Gum Arabic. Journal of Agricultural and Food Chemistry, 56(19), 9269-9276. https://doi.org/10.1021/jf800849a

Mohammadzadeh Milani, J., Emam-Djomeh, Z., Safari, M., Mousavi, M., Ghanbarzadeh, B., \& Philips, G. O. (2007). Physicochemical and emulsifying properties of Barijeh (Ferula gumosa) gum. Iranian Journal of Chemistry and Chemical Engineering (IJCCE), 26(3), $81-88$. 
Muñoz, J., Rincón, F., Carmen Alfaro, M., Zapata, I., de la Fuente, J., Beltrán, O., \& León de Pinto, G. (2007). Rheological properties and surface tension of Acacia tortuosa gum exudate aqueous dispersions. Carbohydrate Polymers, 70(2), 198-205. https://doi.org/10.1016/j.carbpol.2007.03.018

Nguema-Ona, E., Vicré-Gibouin, M., Gotté, M., Plancot, B., Lerouge, P., Bardor, M., \& Driouich, A. (2014). Cell wall O-glycoproteins and N-glycoproteins: aspects of biosynthesis and function. Frontiers in Plant Science, 5. https://doi.org/10.3389/fpls.2014.00499

Ozaki, S., Oki, N., Suzuki, S., \& Kitamura, S. (2010). Structural Characterization and Hypoglycemic Effects of Arabinogalactan-Protein from the Tuberous Cortex of the White-Skinned Sweet Potato (Ipomoea batatas L.). Journal of Agricultural and Food Chemistry, 58(22), 11593-11599. https://doi.org/10.1021/jf101283f

Phillips, G. O. (2009). Molecular association and function of arabinogalactan protein complexes from tree exudates. Structural Chemistry, 20(2), 309-315. https://doi.org/10.1007/s11224-009-9422-3

Phillips, G. O., \& Williams, P. A. (2004). Gums and Stabilisers for the Food Industry 12. The Royal Society of Chemistry. https://doi.org/10.1039/9781847551214

Phillips, G. O., \& Williams, P. A. (2009). Handbook of Hydrocolloids. Elsevier Science. Renou, F., Petibon, O., Malhiac, C., \& Grisel, M. (2013). Effect of xanthan structure on its interaction with locust bean gum: Toward prediction of rheological properties. Food Hydrocolloids, 32(2), 331-340. https://doi.org/10.1016/j.foodhyd.2013.01.012

Sassaki, G. L., Souza, L. M., Serrato, R. V., Cipriani, T. R., Gorin, P. A. J., \& Iacomini, M. (2008). Application of acetate derivatives for gas chromatography-mass spectrometry: Novel approaches on carbohydrates, lipids and amino acids analysis. Journal of Chromatography A, 1208(1-2), 215-222. https://doi.org/10.1016/j.chroma.2008.08.083 
Schulz, G. E. (1977). Structural rules for globular proteins. Angewandte Chemie International Edition in English, 16(1), 23-32.

Shen, T., Li, G.-H., Wang, X.-N., \& Lou, H.-X. (2012). The genus Commiphora: A review of its traditional uses, phytochemistry and pharmacology. Journal of Ethnopharmacology, 142(2), 319-330. https://doi.org/10.1016/j.jep.2012.05.025

Steinhorn, G., Sims, I. M., Carnachan, S. M., Carr, A. J., \& Schlothauer, R. (2011). Isolation and characterisation of arabinogalactan-proteins from New Zealand kanuka honey. Food Chemistry, 128(4), 949-956. https://doi.org/10.1016/j.foodchem.2011.03.124

Tapie, N., Malhiac, C., Hucher, N., \& Grisel, M. (2008). Determination of galactose and mannose residues in natural galactomannans using a fast and efficient high-performance liquid chromatography/UV detection. Journal of Chromatography A, 1181(1-2), 45-50. https://doi.org/10.1016/j.chroma.2007.12.027

Varfolomeeva, E. P., Grinberg, V. Y., \& Tolstogusov, V. B. (1980). On the possibility of estimating weak interactions of macromolecules in solutions from the experimental viscous flow activation energies data. Polymer Bulletin, 2(9), 613-618. https://doi.org/10.1007/BF00263032

Vasile, F. E., Martinez, M. J., Pizones Ruiz-Henestrosa, V. M., Judis, M. A., \& Mazzobre, M. F. (2016). Physicochemical, interfacial and emulsifying properties of a non-conventional exudate gum (Prosopis alba) in comparison with gum arabic. Food Hydrocolloids, 56, 245-253. https://doi.org/10.1016/j.foodhyd.2015.12.016

Vinod, V. T. P., Sashidhar, R. B., Suresh, K. I., Rama Rao, B., Vijaya Saradhi, U. V. R., \& Prabhakar Rao, T. (2008). Morphological, physico-chemical and structural characterization of gum kondagogu (Cochlospermum gossypium): A tree gum from India. Food Hydrocolloids, 22(5), 899-915. https://doi.org/10.1016/j.foodhyd.2007.05.006 
Vlassopoulos, D. (2004). Colloidal star polymers: Models for studying dynamically arrested states in soft matter. Journal of Polymer Science Part B: Polymer Physics, 42(16), 29312941. https://doi.org/10.1002/polb.20152

Wiendl, R. M., Müller, B. M., \& Franz, G. (1995). Proteoglycans from the gum exudate of myrrh. Carbohydrate Polymers, 28(3), 217-226. https://doi.org/10.1016/01448617(95)00150-6 
Table 1: $C A$ gum main characteristics

\begin{tabular}{|l|c|}
\hline Extraction yield (from 10g of nodules) (w\%) & $38 \pm 2$ \\
\hline Moisture (w\%) & $6.6 \pm 0.1$ \\
\hline Ashes (w\%) & $3.73 \pm 0.01$ \\
\hline Proteins (w\%) & $10.2 \pm 0.6$ \\
\hline Carbohydrates (w\%) & $79.5 \pm 0.6$ \\
\hline $\mathrm{pH}($ solution 5 w\%) & $4.9 \pm 0.1$ \\
\hline Optical rotation $\left({ }^{\circ} . \mathrm{dm}^{-1} \cdot \mathrm{g}^{-1} . \mathrm{cm}^{3}\right)$ & $-36.6 \pm 3.4$ \\
\hline
\end{tabular}

Table 2: Monosaccharide composition of the $C A$ gum polysaccharides from HPLC-ESI-MS measurement

\begin{tabular}{|l|l|}
\hline Monosaccharide & Proportion \% $(\mathrm{n}=5)$ \\
\hline Arabinose & $46.90 \pm 0.45$ \\
\hline Galactose & $28.10 \pm 0.45$ \\
\hline Galacturonic acid & $6.87 \pm 0.47$ \\
\hline Mannose & $4.96 \pm 0.28$ \\
\hline Xylose & $4.61 \pm 0.21$ \\
\hline Glucosamine & $4.33 \pm 0.19$ \\
\hline Fucose & $4.24 \pm 0.05$ \\
\hline
\end{tabular}

Table 3: Amino acids composition of the $C A$ gum proteins from GC-MS measurement

\begin{tabular}{|l|c|}
\hline Amino acids & Proportions \% $(\mathrm{n}=3)$ \\
\hline HydroxyProline & $22.7 \pm 4.0$ \\
\hline Proline & $18.1 \pm 1.4$ \\
\hline Alanine & $14.9 \pm 2.0$ \\
\hline Phenylalanine & $8.7 \pm 0.8$ \\
\hline Leucine & $7.1 \pm 0.8$ \\
\hline Serine & $6.2 \pm 1.1$ \\
\hline Glutamic Acid & $6.1 \pm 1.5$ \\
\hline Aspartic Acid & $5.3 \pm 1.8$ \\
\hline Threonine & $4.9 \pm 0.9$ \\
\hline Glycine & $4.3 \pm 0.7$ \\
\hline Isoleucine & $1.2 \pm 0.6$ \\
\hline Valine & $0.9 \pm 0.2$ \\
\hline
\end{tabular}

Table 4: $C A$ gum characteristics from SEC measurement

\begin{tabular}{|l|r|}
\hline Elution time (min) & $19.1-28.5$ \\
\hline $\mathrm{Mw}(\mathrm{g} / \mathrm{mol})$ & 1303000 \\
\hline $\mathrm{Mn}(\mathrm{g} / \mathrm{mol})$ & 258600 \\
\hline Polydispersity & 5 \\
\hline $\mathrm{Rh}(\mathrm{nm})$ & 14.1 \\
\hline$\eta(\mathrm{ml} / \mathrm{g})$ & 22.8 \\
\hline $\mathrm{Rg}(\mathrm{nm})$ (form 19.1 to $24.3 \mathrm{~min})$ & 57.7 \\
\hline
\end{tabular}





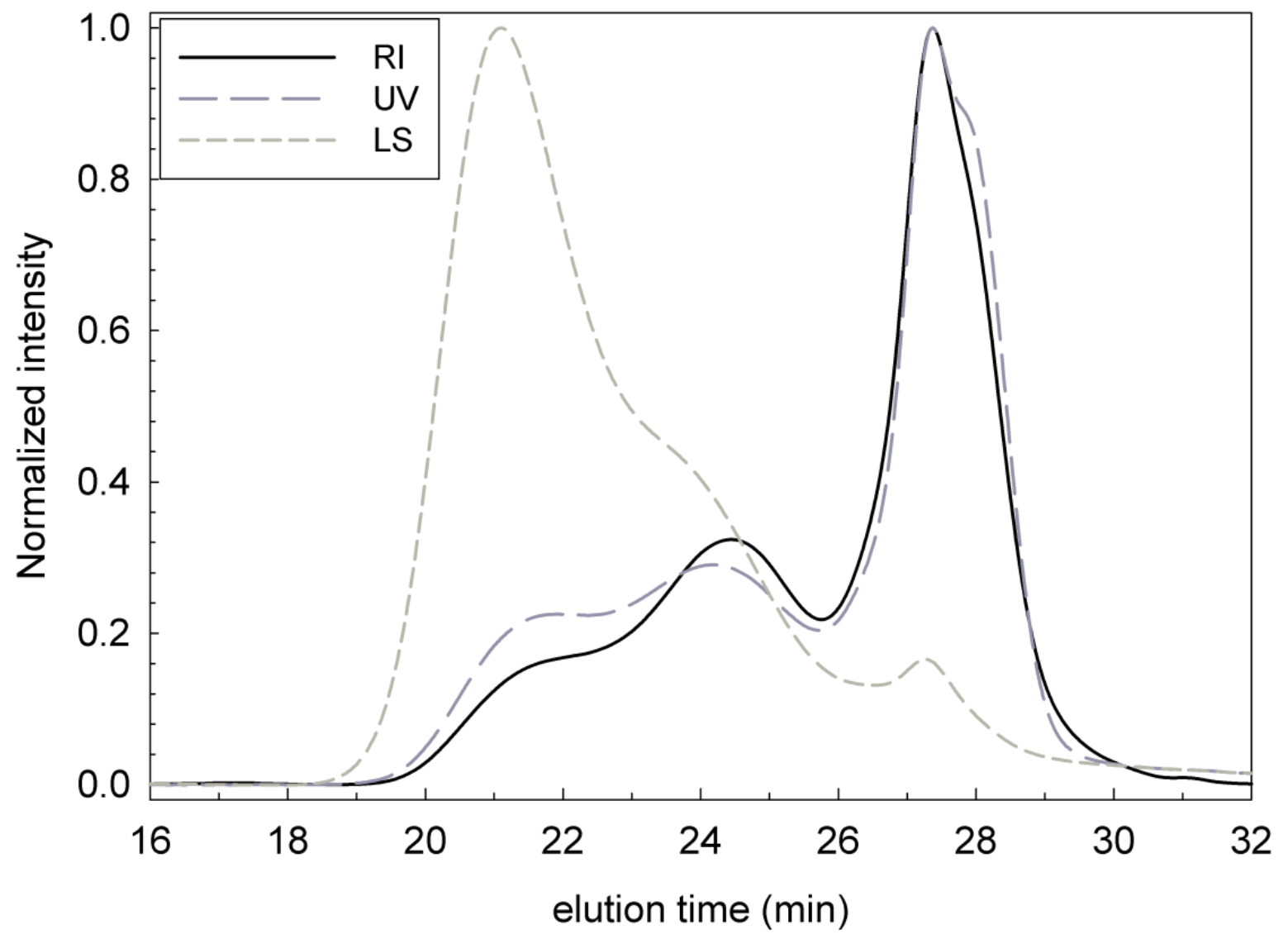

Figure 1. Chromatogram from SEC measurement. Detectors signals from differential refractometer (RI), UV-VIS detector activated at 280nm (UV) and multi-angle laser light scattering (LS). 


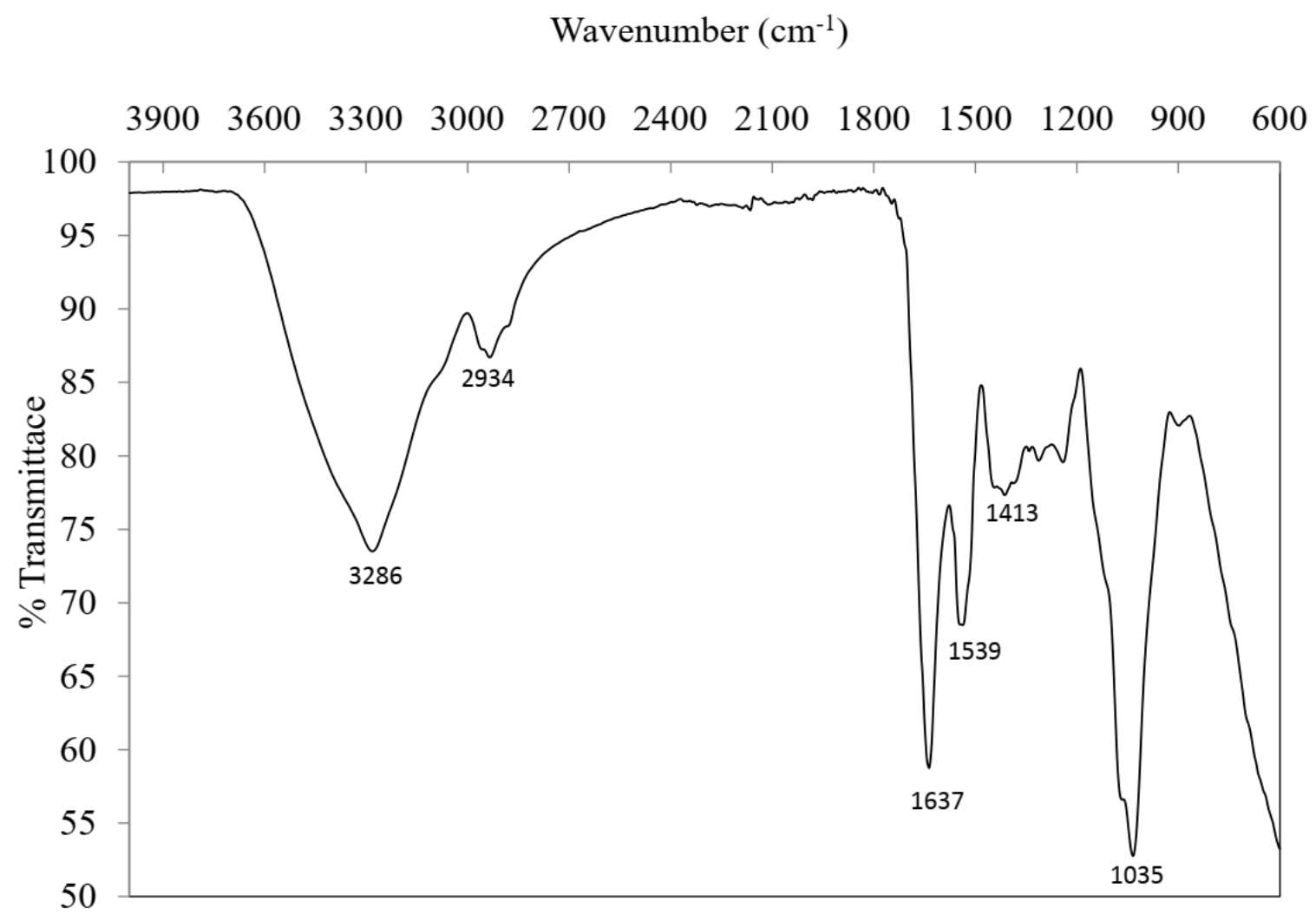

Figure2. ATR FTIR spectrum of $C A$ gum. 


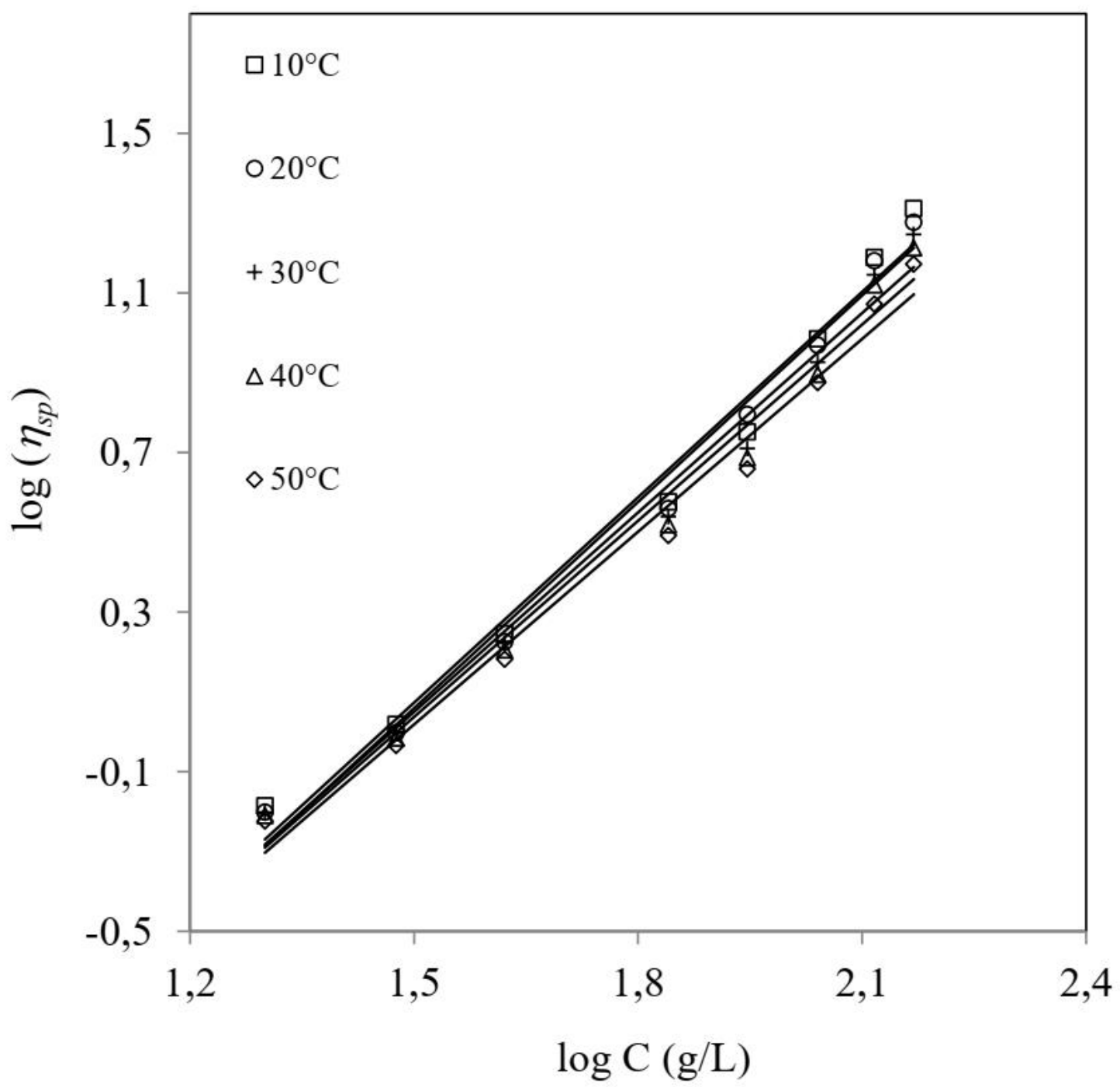

Figure 3. Specific viscosity as a function of $C A$ gum concentration $(\mathrm{g} / \mathrm{L})$ at different temperatures from $10^{\circ} \mathrm{C}$ to $50^{\circ} \mathrm{C}$. 


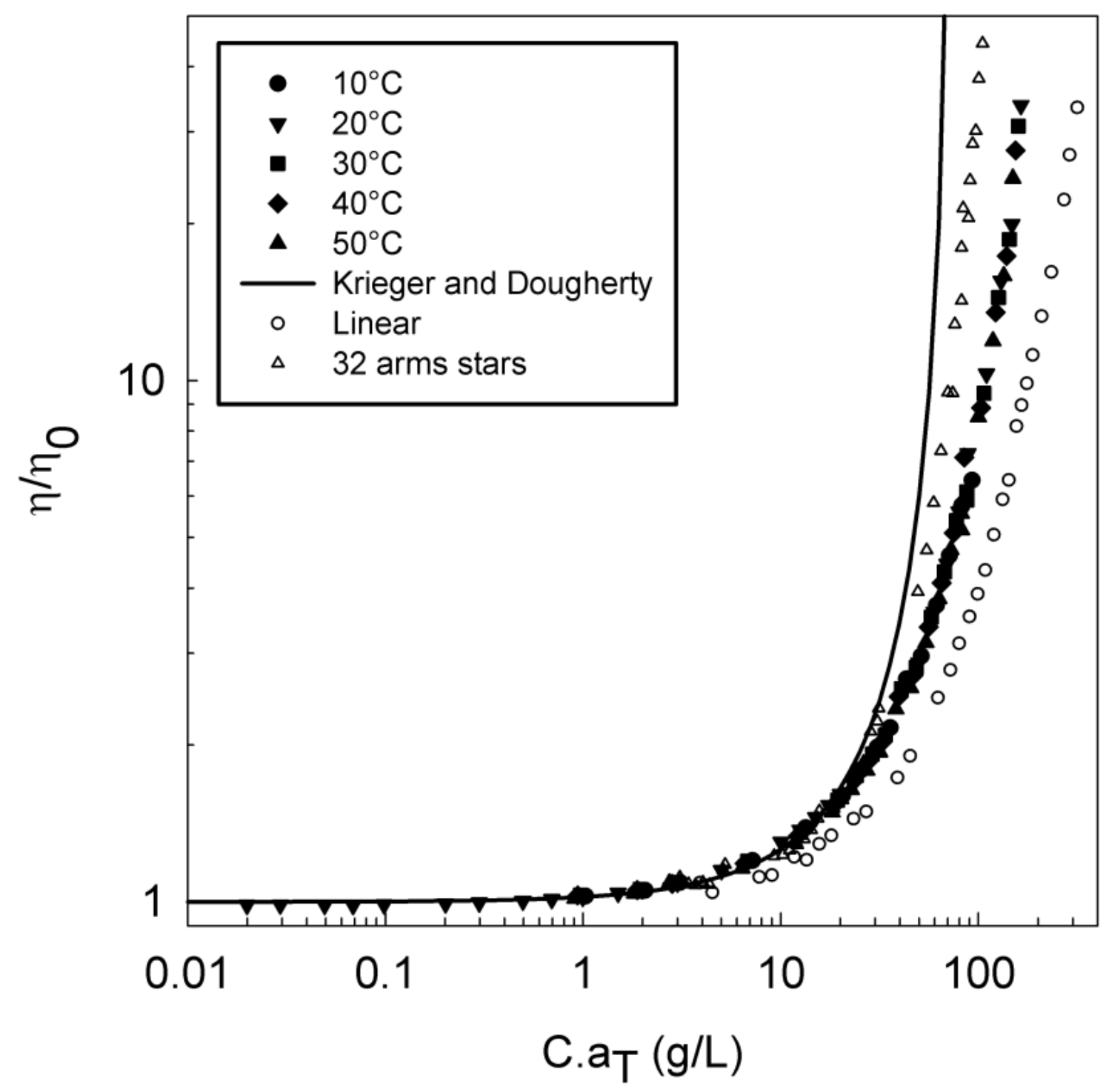

Figure 4. Relative viscosity as a function of concentration of the CA gum solutions (filled symbols). Comparison with Hard Sphere model (line) linear polymer (open circles) and 32 arms starlike polymer (open triangles). 


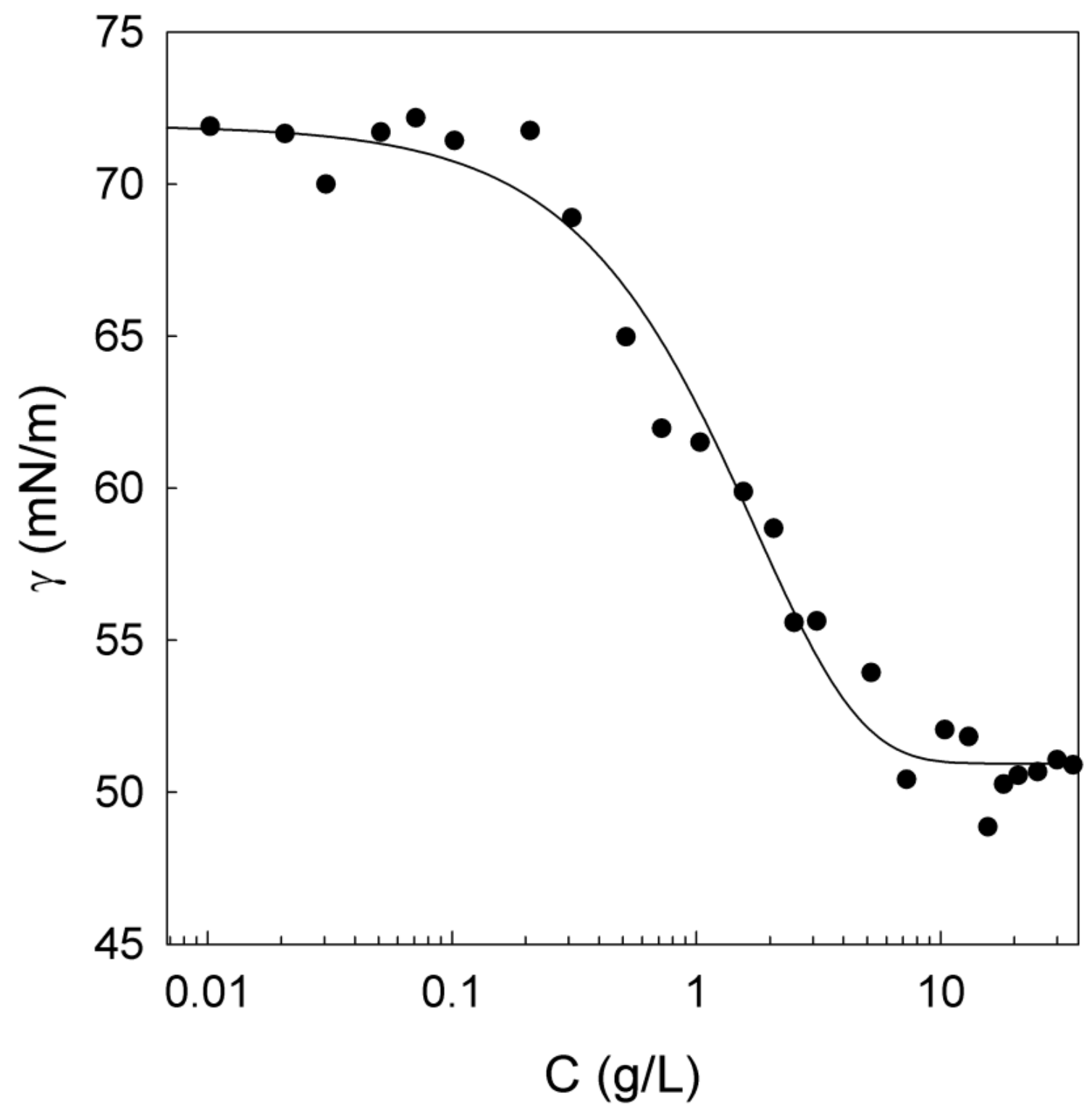

Figure 5. Water surface tension as a function of $C A$ gum concentration. Line represents fit using a single exponential decay. 

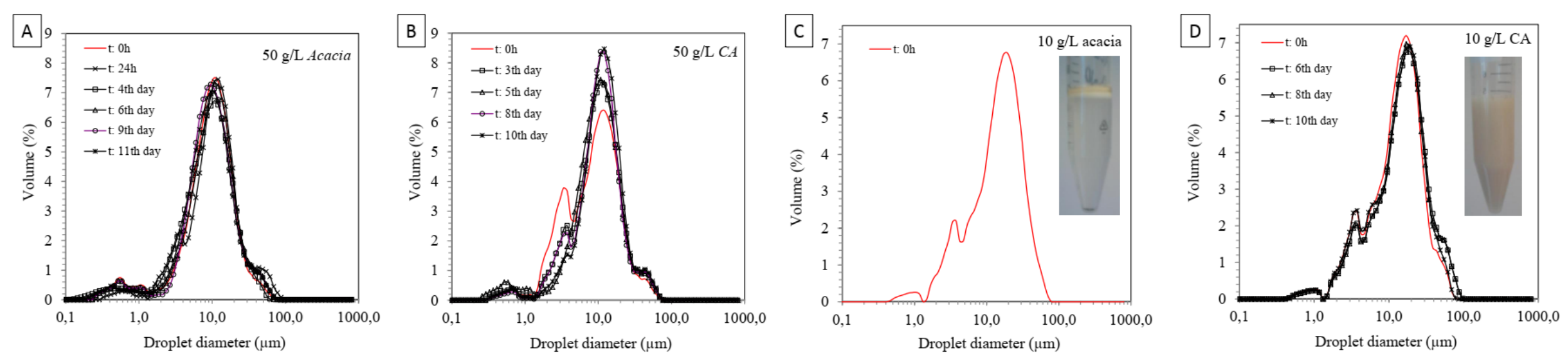

Figure 6: Size and size distribution of droplets in o/w emulsions (orange essential oil/water) prepared from $50 \mathrm{~g} / \mathrm{L}$ of Acacia Senegal (A) or CA gum (B) and $10 \mathrm{~g} / \mathrm{L}$ of Acacia Senegal (C) and CA gum (D). Captions: pictures of emulsion samples 1 hour after emulsification. 